\title{
African American Migration to the Midwest: A Review Essay
}

\author{
ALLISON GORSUCH
}

Emancipation's Diaspora: Race and Reconstruction in the Upper Midwest, by Leslie Schwalm. The John Hope Franklin Series in African American History and Culture. Chapel Hill: University of North Carolina Press, 2009. xii, 387 pp. Illustrations, maps, tables, graphs, notes, bibliography, index. $\$ 65.00$ cloth, $\$ 24.95$ paper.

A Little More Freedom: African Americans Enter the Urban Midwest, 18601930, by Jack Blocker. Urban Life and Urban Landscape Series. Columbus: Ohio State University Press, 2009. xvii, 330 pp. Illustrations, maps, tables, graphs, appendixes, notes, index. $\$ 49.95$ cloth.

LESLIE SCHWALM'S Emancipation's Diaspora: Race and Reconstruction in the Upper Midwest and Jack Blocker's A Little More Freedom: African Americans Enter the Urban Midwest, 1860-1930 are two very different books that expand our historical understanding of black migration and presence in the Midwest after the Civil War. Both works tell the story of southern blacks moving northward to settle in a region loosely defined as "the Midwest." Schwalm's book traces the development and movement of ideas and ideologies as well as people; Blocker's traces the physical movement and economic development of populations. Each work also covers different geographical spaces; Schwalm includes Iowa, Wisconsin, and Minnesota while Blocker profiles Ohio, Indiana, and Illinois. This essay will provide a review of

THE ANNALS OF IOWA 69 (Spring 2010). (C) The State Historical Society of Iowa, 2010. 
each work independently before asking questions raised by these two works: What is the Midwest, and why does that definition matter when studying African American migration? How can historians further the concept of "place" in terms of African American migration?

LESLIE SCHWALM'S Emancipation's Diaspora provides a new look at the Midwest, particularly the state of Iowa, through the legacy of slavery. Schwalm emphasizes that African Americans who lived in the postbellum upper Midwest often had been enslaved themselves. The legacy of slavery influenced the ideas that African Americans living in the postwar Midwest had about this "land of freedom" as they lived, worked, and fought for civil rights (15).

Iowa provides the main stage for this book, and many of its arguments are rooted in Iowa places. Schwalm shows that almost half of Iowa counties received their first black residents between 1860 and 1870; by 1870, only 16 percent of Iowa counties had no black residents. She profiles two small towns with African American residents, Muscatine and Keokuk. The latter became home to many growing African American institutions in the antebellum period. Later, it was the site of escalating racial tensions brought on by the economic crisis of 1857. Keokuk was also a base of black Union enlistment during the war.

Most of Schwalm's sources originated in Iowa, with additional materials from Minnesota, Illinois, Missouri, and Wisconsin. She includes materials from many cities across Iowa, in the form of newspapers, institutional records, family papers, and governmental records. Other sources include slave narratives from other states, the National Archives for war records, and much published primary material. This diversity of sources from men and women, and local and national archives - creates an especially rich base of evidence that tells the story of Iowa, but also of the region and the country as a whole.

Schwalm's work revolves around the experiences of free and enslaved African Americans in Iowa, Minnesota, and Wisconsin. These states - though legally devoid of slavery under the Northwest Ordinance and each state's constitution - participated in the wrenching horror of the slave trade, harbored 
slaves on "sojourn," continued slavery through indentured servitude, and absorbed the "social landscape" of southern slavery (3). Black laws prevented free African Americans from settling in Iowa. Minnesota and Wisconsin also considered bills to restrict black migration, although the bills never passed. Seen through such laws, attitudes of racial hierarchy meant that as black southerners made their way north - or as northern black residents made their way through life - white midwesterners felt threatened by the social mobility of African Americans signified through their physical mobility from South to North. White midwesterners tried in different ways to restrict blacks' physical mobility through laws, discrimination, and violence. Part of the Midwest's contract with the Union, it seemed, was that African Americans would remain a southern problem. When the Civil War began, that contract was suddenly broken.

After the outbreak of the Civil War, African Americans began moving to the Midwest in greater numbers. Black men and women used the war as a chance to move north; more than 6,000 African Americans escaped slavery while the Civil War raged. At first, official Union policy did not support escaping slaves, and troops often returned slaves to their masters. After the passage of the Confiscation Act and the issuance of the Emancipation Proclamation, that practice diminished. The war also provided an opportunity for freedom for slaves in the Union slave states of Missouri and Kentucky; although the proclamation did not apply to those border states, they were the source of over a third of the sampled wartime migrants to the upper Midwest.

Enslaved people who seized the opportunity of wartime disruption to leave their masters took a number of different paths. More than 70,000 black men signed up to serve in the Union army. The war also provided an opportunity for women - who previously had fewer opportunities to escape slavery - to free themselves by moving behind Union army lines. Some women moved north in informal arrangements with Union soldiers to assist those midwestern soldiers' families at home - a dubious escape from slavery, but part of the diversity of wartime migration experience that Schwalm uncovers. Another wartime migration movement began in 1862, when former slaves found 
themselves in relocation camps as part of an organized relocation movement. Traveling in boxcars, large numbers of formerly enslaved people - mainly women and children - were moved to border places such as Cairo, Illinois, and St. Louis, Missouri, and then on to other towns in Wisconsin, Minnesota, and Iowa. Such government-organized relocations were not only uncomfortable but unsafe due to threats of slave kidnappers and violence. By showing the on-the-ground experiences of black migrants during the Civil War, Schwalm changes the face of the wartime Midwest: not only were African Americans migrating northward, but they also found racism and violence alive and well there as in the South.

As these newly free African Americans made their way north during the war, white midwesterners came to a new realization: "that the consequences of emancipation extended well beyond the slaveholding South" (81). White midwesterners saw relief for freedmen as stealing from white families who had also been hit hard by the war, especially those living in areas with white-Indian conflict. Restrictive black laws were a way to control the perceived threat of black immigration; in Iowa, white residents celebrated an anniversary of the Emancipation Proclamation before beginning legal proceedings against a freed slave who had emigrated in violation of an 1851 law. Because the refugees from the South were often women working for white women, conflict was not simply racialized but also gendered, as white men felt their authority threatened. The war had disrupted the way things were.

This sense of disruption continued in many aspects of midwestern life. Free black men who had previously migrated north later enlisted in the military, much to the discomfort of white midwesterners. Even though black soldiers were a military necessity - helping "turn the tide of war" for a Union victory - white midwesterners resisted black enlistment because, as Schwalm puts it, "recent arrivals in the upper Midwest . . . linked their geographic migration to their social migration from slaves to contraband property, from contrabands to soldiers, from soldiers to citizens" (108). But at no point were black soldiers guaranteed acceptance and citizenship because of their service. In fact, northern whites eventually agreed with the policy 
of enlisting black men because it would prevent those black men from settling immediately in the North and lessened the need for a draft. Despite these circumstances, many African Americans viewed soldiering as an important step to full citizenship, although some protested their unfair working conditions.

Keokuk, Iowa, became the rendezvous point for black enlistment in the Mississippi River valley because of Missouri's restrictive laws on arming African Americans. That concentration of enlistment allows Schwalm to argue, using pension records, that the great majority of men enlisting were former slaves, not people who had been free before the war. The records of the 60th Regiment - Iowa's "Colored Infantry" regiment - show the potential for great change during wartime: black men changed their surnames upon enlistment, worked hard to defy the public perception of black men as lazy or oversexed, and returned to the South to fight for the Union. Those soldiers' working conditions were brutal, the work was strenuous and uncelebrated, and disease was rampant. The call to serve extended as well to some African American women who accompanied their husbands to war as unofficial nurses and cooks.

After the Civil War, the legacy of slavery continued to influence life for both white and black midwesterners. Economic opportunity brought many black migrants to places like Keokuk, but they soon found that jobs for black people were low paying and menial, with industrial and professional employment inaccessible. Women worked as domestic laborers, often as servants. Men were mostly day laborers. The meager wages they earned went to keeping their families; any extra earnings went to the new AME and Baptist churches in Muscatine and Keokuk. Such institutions as fraternal organizations, churches, and political groups were spaces for public discourse, especially about gender and sexuality. For example, gender roles were often discussed in churches, where ideas grew increasingly conservative. Women had a voice in church proceedings, but were often overruled by men. In reality, it took black men and women together to build a church, but the dynamics of race and gender took their toll on religious equality. When black men were the subject of racialized and stereotyping attacks by whites, as they 
often were in the postwar period, they responded by reinforcing their gendered roles. That gendering of the black community was an effect of the midwestern legacy of slavery.

As a result, it was black men who built the fraternal organizations that "became principal sites for the articulation of evolving racial ideologies, race organizing, and masculine identity" (157). Schwalm's discussion of these fraternal organizations stresses the ways gender and race influenced the organization of various lodges across the Midwest, especially Prince Hall Masonry. Many white Masons resisted the inclusion of black lodges, although black Masons "engaged in an extensive but focused campaign against white Masonic racism" (164). By 1881, Iowa had 11 Prince Hall lodges with 250 members and it was time for a Grand Lodge open to blacks. This campaign for institutional freedom from the Missouri-controlled parent organization replete with white supremacy marked an important step for African American culture, although it came at the expense of women by promoting patriarchal black male authority.

The questions of earlier chapters - how slavery and Reconstruction were received by midwestern whites as southern problems were brought north - come into clearer focus as Schwalm turns her attention to African Americans' fight for citizenship in the postbellum period. As Schwalm notes, many historians ignore the northern battles for education, suffrage, and citizenship - especially those fought by women. As black men struggled for the right to vote, they also wanted to serve on juries and receive equal public accommodation, while black women fought for equal access to public education and civil rights. Wisconsin, Minnesota, and Iowa did enfranchise men before the Fifteenth Amendment. Yet, as voting became possible, jury service remained forbidden. Black men's allegiance to the Republican Party went unrewarded, as the political power of Lincoln's party was in decline, and what remained was not used for black rights. Racism, although subtle, was present in the Midwest just as in the South, and the North's legal framework "protected white supremacy" just as the South's legal system was being dismantled under Reconstruction (181).

Black women increased their demands in a different way in the courtroom. Cases demanding access to public schools 
and public transit were often brought by black women. Beginning in 1850, Iowa limited black children's access to schools, so black parents organized their own schools. Women brought legal and social challenges in courtrooms and classrooms across the Midwest, especially in Iowa. In 1876 two successful court cases brought school desegregation to Iowa. Public transportation cases provided another site of successful challenge for black women. That success had a darker side, though, as the schools that had been successfully founded and run by black parents were now under white control, and black women lost their jobs as teachers.

In 1883 the federal Civil Rights Act was withdrawn and state legislation was still not strong enough to protect the rights of African Americans, leaving black midwesterners frustrated with their "circumscribed political power" (207). Two years later, black midwesterners forged a new way of challenging limited civil rights. Black women began to work with black men, white women, and their own support organizations to achieve change in different arenas. Interracial suffrage movements grew in Iowa, national African American groups formed branches in the Midwest, and women's clubs sprouted up across the country. Despite such efforts, racism and sexism still kept civil rights out of reach.

The legacy of slavery and the Civil War was felt as much in the Midwest as anywhere else. A "culture of reunion" rid the war of any recollection of divisive arguments over substantive issues, and the white media portrayed slavery as a fond memory. The brutal history of midwestern slavery was forgotten, and white midwesterners could pat themselves on the back for their roles in the war and the Underground Railroad. African Americans in Iowa spoke out against such representations through speeches, Emancipation Day celebrations, and other avenues. By the turn of the twentieth century, black women were taking a more outspoken role. Black veterans groups and women's auxiliaries became increasingly important.

Schwalm shows, through detailed research, that slavery was a continued subject of African American conversation and memory. From pension claims, in which women documented their own actions in achieving freedom and always mentioned their 
slave pasts, to death notices and obituaries that noted membership in fraternal groups as well as talking about slavery, to slave narratives published by black midwesterners, such documents challenged the dominant contemporary narrative of slavery as something that was only part of a nostalgic southern past. They also challenge current assumptions about the extent to which northern African Americans felt connected with their southern history. Schwalm finds that these memories of slavery have "no corresponding memory of the wide-ranging Reconstruction-era activism for citizenship and civil rights" (262). Even though they were in the upper Midwest, a land that had long been free, African Americans still saw slavery as the most salient issue for their past, present, and future.

Emancipation's Diaspora is an important book for all scholars of midwestern history, as it brings to light the Civil War-era African American experience in the North and Midwest. Schwalm's consistent emphasis on gender and race dynamics makes this an especially well-rounded story. The regional focus of African American migration from the border regions and the Mississippi slave south to Iowa, Minnesota, and Wisconsin gives crucial evidence of why the subject of slavery and emancipation is, and should be, important for historians of the Midwest. White midwesterners may have seen themselves as northerners, separated from the South and its brutal legacy of slavery and oppression, but geography - and Schwalm's exemplary research - prove otherwise.

JACK S. BLOCKER'S A Little More Freedom tells the story of the more than 750,000 African American migrants to Ohio, Indiana, and Illinois between 1860 and the beginning of the Great Depression. In the first and second parts of his book, Blocker profiles small towns in the Midwest. He primarily uses quantitative methods, but also includes material from memoirs and oral history sources. He aims to show how black migration occurred, examining whether African Americans moved directly to large urban areas or chose to move in "step migration" from town to town until they reached a final destination. In the third part, Blocker looks at the southern conditions that might have contributed to midwestern migration. 
The first wave of northward migration occurred during the Civil War period. That movement included mostly poor black families, assisted by white people. Before 1890, migrants were more likely to participate in step migration, meaning that people would move to small towns for short periods of time before settling in a larger city. African Americans chose where to migrate based not on where existing African American communities were located, but where the population was growing quickly and had a rural character that meshed well with the migrants' previous experience. Laws restricting African American settlement in the Midwest also influenced migrants' choices.

Even in this hostile climate, African Americans worked hard to simultaneously build community institutions and achieve political and economic parity in their "adopted communities." In Washington Court House, Ohio, a number of African American families were able to build wealth, even though they were limited to a small number of unskilled occupations. Two small cities called Springfield - one in Illinois, one in Ohio - also became targets for African American migration. Springfield, Ohio, was an industrial city that attracted African Americans mostly from Kentucky, mostly men whom factories employed for the intense labor of metalworking. Housing was less racially segregated than in other towns; work for women was more varied. It also had lower than average homeownership rates and higher rates of black men living with non-kin, which Blocker suggests might be because of the lack of job advancement for African Americans - evidence of white labor groups' growing fear of job competition from blacks, which would manifest itself in the form of racial violence after 1900.

Springfield, Illinois, had a more varied economy than the Ohio metalworking town, attracting families from Kentucky, Tennessee, and Virginia. However, that capital city, home of the "Great Emancipator" Abraham Lincoln, was not nearly as popular with black migrants as Springfield, Ohio. Homeownership rates were higher than in many other towns, though still affected by the restricted availability of jobs. Using homeownership data from the Springfields and Washington Court House, Blocker suggests that the economic penalties usually inflicted on black families by work discrimination may have been mitigated in 
less urban towns, compared to large cities, perhaps because of the economic power and homeownership rates of African American women. Still, larger cities such as the Springfields were more economically profitable for black families over the long run than smaller towns like Washington Court House. African American migrants employed many strategies for success; living in a big or small town, moving or staying, could all be avenues to homeownership and financial stability.

At the beginning of the twentieth century, race relations were deteriorating across the country, no less in the Midwest. Political activism on the part of black families added to the tension felt by the northern white majority. Metropolitan black families developed their political activism through their migration via smaller towns, where they learned the power of their vote. In Ohio African American votes were in demand before the turn of the century by both parties. Yet, by 1900, politicians had abandoned African American interests, even though smalltown African Americans did achieve some political success through their activism.

Conflict also extended beyond the ballot box. As African Americans tried to build new lives in their midwestern homes, white residents saw their new neighbors as "transgressors of ... community mores" (91). Local police were far harsher on black residents than on whites in Washington Court House, Xenia, and other midwestern towns. Even in states with school desegregation laws, local enforcement was difficult. Labor battles in Ohio, Indiana, and Illinois also put African Americans in a tight spot; even though some interracial labor movements had taken off in the 1880s, by the end of that decade the white labor movement had closed its doors to alliances with black workers.

In such circumstances, African Americans continued to work for their political rights, but any political disruption by black midwesterners could lead to violence. The same towns in which African Americans established schools and churches, purchased houses, and raised families in the postwar period became increasingly violent over the 1880s and 1890s. Illinois, Ohio, and Indiana all experienced antiblack violence, often in the same pattern as border states. Conflicts over politics, strikes, and private revenge all prompted terrorist mobs in the Mid- 
west, with little protection available to black residents from the police or other state forces.

All of this violence was intensely local. Close examination of stories of midwestern violence in the towns profiled earlier in the book brings the narrative of antiblack violence closer to home and integrates it into the story of migration. In places such as Washington Court House - previously very attractive to black migrants - racial violence, along with job discrimination, caused black migration to stop in the 1890s. Although there were similarities, antiblack violence in the Midwest differed from that in the South in three ways: it was spread out over the year rather than peaking in the summer, "spectacle lynching" was absent, and antiblack violence remained steady in the North over the turn of the century as it declined in the South.

The largest explosions of antiblack violence occurred in Springfield, Illinois, during two "full-scale race riots" (123). There, white mobs targeted saloons owned by African Americans, indicating that white men may have felt threatened by African Americans' social and class movement. Violent outbursts such as these in the lower Midwest have largely been ignored, even though lynching rates in the lower Midwest during the first decade of the twentieth century equaled those in Georgia and Virginia. Blocker points to the North's relatively egalitarian laws, noting that in the South increasing legal restrictions on black freedoms meant that southern whites maintained control without having to resort to violence.

African American public voices in the North denounced the racial violence, except in the few cases of black self-defense. For example, the riots in Springfield, Illinois, in 1908 included instances of newspapers positively reporting black Springfield residents fighting back against white violence. Local oral history as well as newspaper reports from the time emphasize African American agency - and that agency extended to many African Americans leaving a town they felt was no longer safe. Black Springfield residents were not just passive victims.

After this period of violence, midwestern migration changed. African American migrants in the 1920s encountered new challenges, which they faced with established resources from those migrants who had settled in the Midwest over the previous 50 
years. The newer migrants often came from southern cities. Migration from Kentucky flowed to the urban North, while that from Alabama and Mississippi tended to the West, with African Americans moving for agricultural independence, not urban settlement, although there was some in-state urbanization as well. Tennessee migrants split between the rural Southwest and the urban North.

By the turn of the century, most migrating people, regardless of race, were moving to cities, although African Americans often chose to live in places with less racial violence. Indianapolis, for example, was a peaceful town, with African American institutions, although it lacked a booming economy. By 1890, Chicago had a large African American population, with more migrants coming for booming job opportunities despite its violent history. The potential for violence and economic opportunity had to be balanced when choosing a town.

In the 1910s the migration "trickle" suddenly became a deluge. World War I brought the First Great Migration of southern blacks to the North. Blocker emphasizes that this migration was a continuation of previous migration practices and was simply one of many options available to southern black people. African American migration patterns after 1910 showed less preference for established African American communities and essentially followed economic opportunities, paralleling white migration patterns. Cities that had positive hiring practices for African Americans, such as Cleveland, Ohio, became especially popular. There was also a growing sense of safety in numbers, and increasing numbers of migrants had previously lived in an urban place in the South, so felt they could bypass the small-town stop.

Blocker emphasizes, however, that no single contributing factor explains any of these patterns. Some migrants chose to live in small towns, perhaps for the availability of homeownership. A combination of antiblack violence, black institutions, and economic opportunity provided the variables for this decision. The process of migration also contributed to a growing racial consciousness, as the racism of the small-town Midwest and the vibrant black communities of northern cities created a push and pull effect on not only physical movement but on cul- 
tural consciousness as well. In this way, Blocker says, the Midwest influenced its new African American residents as much as the new migrants changed the Midwest.

A number of impressive addendums add immensely to the value of Blocker's book. Three appendixes provide a wealth of information, including statistics, a bibliography of primary and secondary works, and commentary on migrant oral history. The tables and charts available throughout the work provide excellent visual and numerical support for his arguments. These appendixes provide a way to compare the different cities and time periods of the book, which spans three states and, at points, up to 70 years of time.

BETWEEN THESE TWO BOOKS, six states of the midwestern portion of the United States are profiled. Schwalm covers Iowa, Wisconsin, and Minnesota while Blocker covers Ohio, Indiana, and Illinois. Perhaps one of the main impressions from these two works is that the term "the Midwest" needs more definition. Schwalm deems her region "the Upper Midwest" and Blocker his region "the urban Midwest"; both need further clarification, because from the evidence posed in these two books, the African American experience in Des Moines and Indianapolis may have differed, even though both may have been "urban" areas in the "Midwest."

Both Blocker and Schwalm wrestle with the idea of social and physical places. Blocker notes that racial violence by whites may have been caused, as in the South, by whites perceiving that African Americans were ignoring the subordinate place given to them by white society through striving for full citizenship. Schwalm writes repeatedly about the perceived double threat of African American migration: not only were black people settling in previously white-only geographic areas; they were also working to improve their economic and social situations. Both authors come to a similar conclusion based on their regional study, but upon comparison one then wonders what was regional about that conclusion at all. Is this a midwestern story, or are there differences between the Midwest and other parts of the Union North, or even among the states of the Midwest? Was "place" specific to place? 
Both of these works are relevant for scholars of African American history and midwestern history. Schwalm's book is especially useful for historians interested in Iowa, as well as those studying black Civil War soldiers. Each book uses very different methods, providing scholars with complementary material: Blocker combines probing statistical analysis of regionwide movements with in-depth profiles of specific towns at different points in time; Schwalm focuses on cultural sources to build a broad picture of black experiences and changes. By appreciating both works side by side, one can see a more holistic picture of the state of black affairs in the Midwest. For example, Schwalm has an entire chapter on black cultural, fraternal, and religious institutions in Iowa - of which Blocker's families in Ohio were also members, but he mentions only in passing. As part of a growing field of African American history in the Midwest, these two books offer important contributions and perspectives. 